\title{
PERBEDAAN TEKANAN DARAH PADA ANAK YANG TINGGAL DI PEGUNUNGAN DAN TINGGAL DI TEPI PANTAI
}

\author{
${ }^{1}$ Alan J. Jufri \\ ${ }^{2}$ Adrian Umboh \\ ${ }^{2}$ Nurhayati Masloman \\ ${ }^{1}$ Kandidat Skripsi Fakultas Kedokteran Universitas Sam Ratulangi Manado \\ ${ }^{2}$ Bagian Ilmu Kesehatan Anak Universitas Sam Ratulangi Manado \\ Email: alanjulanda@gmail.com
}

\begin{abstract}
Blood pressure is the force that is necessary for blood to flow in blood vessels and circulation to all parts of the human body. The air pressure in the mountains is lower than at the beach, this causes increased erythrocyte production, which results in increased viscocity and resistance. This study aimed to determine the difference in blood pressure among children who live in the mountains and at the seaside. This was an observational survey with a cross sectional design. Samples taken to represent the two major populations were elementary students Wulurmaatus Modoinding, South Minahasa (mountain area) and elementary students Inpres 12/79 Wangurer, Madidir Bitung (beach area). In the target population sampling is done by simple random sampling and at affordable population sampling conducted consecutive sampling. Found as many as 28 boys in the mountains and 24 boys on the beach with an average TDS respectively $90.3 \mathrm{mmHg}$ and 94.1 $\mathrm{mmHg}(\rho=0.126)$ and the average TDD respectively $62,1 \mathrm{mmHg}$ and $64.7 \mathrm{mmHg}(\rho=0.146)$. And as many as 25 girls in the mountains and 28 girls on the beach with an average TDS respectively $88.7 \mathrm{mmHg}$ and $93.5 \mathrm{mmHg}(\rho=0.065)$ and the average TDD found respectively 63.7 $\mathrm{mmHg}$ and $66 \mathrm{mmHg}(\rho=0.139)$. From the results obtained it can be concluded that there was no difference in blood pressure (systolic and diastolic) in children who live in the mountains and at the seaside.
\end{abstract}

Keywords: blood pressure, children, mountains, beach front

\begin{abstract}
Abstrak: Tekanan darah merupakan kekuatan yang diperlukan agar darah dapat mengalir di dalam pembuluh darah dan beredar ke seluruh bagian tubuh manusia. Tekanan udara di pegunungan lebih rendah di bandingkan di tepi pantai; hal ini meningkatkan produksi eritrosit, yang mengakibatkan peningkatan viskositas serta resistensi, Penelitian ini bertujuan untuk mengetahui perbedaan tekanan darah pada anak yang tinggal di pegunungan dan di tepi pantai. Penelitian ini bersifat survei observasional dengan rancangan potong lintang. Sampel diambil mewakili ke dua populasi, yaitu siswa SD Inpres Wulurmaatus Kecamatan Modoinding, Kabupaten Minahasa Selatan (pegunungan) dan siswa SD Inpres 12/79 Wangurer, Kecamatan Madidir Kota Bitung (tepi pantai). Pada populasi target pengambilan sampel dilakukan secara simple random sampling dan pada populasi terjangkau pengambilan sampel dilakukan secara consecutive sampling. Ditemukan sebanyak 28 anak laki-laki di pegunungan dan 24 anak laki-laki di tepi pantai dengan rata-rata TDS masing-masing $90,3 \mathrm{mmHg}$ dan $94,1 \mathrm{mmHg}(\rho=0,126)$ serta rata-rata TDD masing-masing $62,1 \mathrm{mmHg}$ dan $64,7 \mathrm{mmHg}(\rho=0,146)$. Sebanyak 25 anak perempuan di pegunungan dan 28 anak perempuan di tepi pantai dengan rata-rata TDS masing-masing $88,7 \mathrm{mmHg}$ dan $93,5 \mathrm{mmHg}$ $(\rho=0,065)$ serta rata-rata TDD ditemukan masing-masing $63,7 \mathrm{mmHg}$ dan $66 \mathrm{mmHg}(\rho=0,139)$. Simpulan: Tidak terdapat perbedaan tekanan darah (sistolik dan diastolik) pada anak yang yang tinggal di pegunungan dan di tepi pantai.
\end{abstract}

Kata kunci: tekanan darah, anak, pegunungan, tepi pantai 
Tekanan darah adalah kekuatan yang diperlukan agar darah dapat mengalir di dalam pembuluh darah dan beredar ke seluruh bagian tubuh manusia.Darah yang dengan lancar beredar ke seluruh bagian tubuh berfungsi sangat penting sebagai media pengangkut Oksigen serta zat-zat lain yang diperlukan bagi kehidupan sel-sel tubuh. ${ }^{1}$

Siklus jantung terdiri atas periode relaksasi yang dinamakan diastole diikuti oleh periode kontraksi yang dinamakan systole. $^{2}$

Tekanan darah normal pada anak adalah tekanan darah sistolik (TDS) dan tekanan darah diastolik (TDD) di bawah persentil 90 berdasarkan jenis kelamin, usia dan tinggi badan. ${ }^{3}$

Terdapat dua macam kelainan tekanan darah yaitu yang dikenal sebagai hipertensi atau tekanan darah tinggi dan hipotensi atau tekanan darah rendah. ${ }^{4}$

Buch dkk dalam penelitian mereka pada anak-anak umur 6-18 tahun, pada total 1.249 anak, 727 anak laki-laki dan 511 anak perempuan, ditemukan sebanyak 49 anak laki-laki dengan hipertensi, sedangkan pada anak perempuan sebanyak 32 dengan hipertensi. ${ }^{5}$

Berdasarkan Riset Kesehatan Dasar (Riskesdas) 2007, prevalensi hipertensi di Sulawesi Utara adalah 31,2\%. Prevalensi hipertensi tertinggi di kepulauan Natuna (pesisir pantai) sebanyak 53,3\%, sedangkan terendah di pegunungan Jayawijaya sebanyak $6,8 \%{ }^{6}$

Menurut hasil Riset Kesehatan Dasar (RISKESDAS) tahun 2013 di Indonesia, prevalensi nasional hipertensi pada anak remaja yaitu 5,3\% (laki-laki 6,0\% dan perempuan 4,7\%), di mana pedesaan (5,6\%) lebih tinggi dari perkotaan $(5,1 \%)$. Namun, hasil tersebut dilakukan dengan analisis hipertensi terbatas hanya pada usia 15-17 tahun menurut kriteria JNC VII 2003. ${ }^{7}$

Menurut Bustan, orang yang tinggal di daerah kota lebih banyak ditemukan adanya hipertensi dibandingkan orang yang hidup di desa, selain itu letak geografis dimana daerah pantai lebih banyak kejadian hipertensi dari pada daerah pegunungan. ${ }^{8}$

\section{METODE PENELITIAN}

Penelitian ini bersifat survei observasional dengan rancangan cross sectional study. Subjek merupakan Siswa SD yang berumur 6-12 tahun yang terdaftar di SD Inpres Wulurmaatus Kecamatan Modoinding, Kabupaten Minahasa Selatan (pegunungan) dan di SD Inpres 12/79 Wangurer, Kecamatan Madidir Kota Bitung (tepi pantai). Penelitian dilakukan selama bulan September 2014 sampai Desember 2014. Data yang telah didapatkan, kemudian dikumpulkan dan diolah dengan dilakukan uji non parametric dengan menggunakan Mann-Whitney Test.

\section{HASIL PENELITIAN}

Penelitian ini dilaksanakan pada SD Inpres Wulurmaatus Kecamatan Modoinding, Kabupaten Minahasa Selatan dengan ketinggian $\pm 1200 \mathrm{~m}$ dari permukaan laut. Dari 89 murid yang terdaftar, sebanyak 64 anak bersedia mengikuti penelitian dan melalui kuesioner didapati 9 anak memiliki salah satu riwayat penyakit keluarga (hipertensi, penyakit jantung dan stroke), 2 orang didapati obesitas dan 53 anak tanpa riwayat keluarga.

Untuk daerah tepi pantai, dilaksanakan di SD Inpres 12/79 Wangurer Kecamatan Madidir Kota Bitung dengan jarak dari pantai $\pm 400 \mathrm{~m}$ dengan ketinggian dari permukaan laut 0-3 m. Dari 350 murid yang terdaftar, sebanyak 60 anak bersedia mengikuti penelitian dan melalui kuesioner didapati 8 anak memiliki salah satu riwayat penyakit keluarga (hipertensi, penyakit jantung dan stroke) dan 52 anak tanpa riwayat keluarga.

Jumlah sampel yang dianalisis 53 anak pada daerah pegunungan dan 52 anak di daerah tepi pantai. Keseluruhan sampel 105 anak. 
Tabel 1. Distribusi data berdasarkan jenis kelamin

\begin{tabular}{|c|c|c|c|}
\hline \multicolumn{4}{|c|}{ Tempat Tinggal } \\
\hline Jenis Kelamin & $\begin{array}{c}\text { Pegunungan } \\
n(\%)\end{array}$ & $\begin{array}{c}\text { Tepi Pantai } \\
\text { n(\%) }\end{array}$ & Jumlah \\
\hline Laki-laki & $28(53)$ & $24(46)$ & $52(49,5)$ \\
\hline Perempuan & $25(47)$ & $28(54)$ & $53(50,5)$ \\
\hline Jumlah & $53(100)$ & $52(100)$ & $105(100)$ \\
\hline
\end{tabular}

Keterangan: \% ialah persentase terhadap total pegunungan (53) dan tepi pantai (52)

Tabel 2. Distribusi tekanan darah sistolik berdasarkan jenis kelamin

\begin{tabular}{ccccccccc}
\hline Jenis & \multicolumn{3}{c}{ Pegunungan } & \multirow{2}{*}{ Jumlah } & \multicolumn{3}{c}{ Tepi Pantai } & \multirow{2}{*}{ Jumlah } \\
Kelamin & $\mathrm{N}(\%)$ & $\mathrm{NT}(\%)$ & $\mathrm{T}(\%)$ & & $\mathrm{N}(\%)$ & $\mathrm{NT}(\%)$ & $\mathrm{T}(\%)$ & \\
\hline $\mathrm{L}$ & $27(51,1)$ & 0 & $1(1,9)$ & $28(53)$ & $23(44,1)$ & 0 & $1(1,9)$ & $24(46)$ \\
$\mathrm{P}$ & $25(47)$ & 0 & 0 & $25(47)$ & $27(52,1)$ & $1(1,9)$ & 0 & $28(54)$ \\
& & & & & & & & \\
Jumlah & $52(98,1)$ & 0 & $1(1,9)$ & $53(100)$ & $50(96,2)$ & $1(1,9)$ & $1(1,9)$ & $52(100)$ \\
\hline
\end{tabular}

Keterangan: $\mathrm{N}=$ Normal NT= Normal Tinggi $\mathrm{T}=$ Tinggi

Tabel 3. Distribusi tekanan darah diastolik berdasarkan jenis kelamin

\begin{tabular}{ccccccccc}
\hline Jenis & \multicolumn{3}{c}{ Pegunungan } & \multirow{2}{*}{ Jumlah } & \multicolumn{3}{c}{ Tepi Pantai } \\
Kelamin & $\mathrm{N}(\%)$ & $\mathrm{NT}(\%)$ & $\mathrm{T}(\%)$ & & $\mathrm{N}(\%)$ & $\mathrm{NT}(\%)$ & $\mathrm{T}(\%)$ & \multirow{2}{*}{ Jumlah } \\
\hline L & $25(47,3)$ & $2(3,8)$ & $1(1,9)$ & $28(53)$ & $21(40,2)$ & 0 & $3(5,8)$ & $24(46)$ \\
P & $25(47)$ & 0 & 0 & $25(47)$ & $23(44,4)$ & 0 & $5(9,6)$ & $28(54)$ \\
Jumlah & $50(94,3)$ & $2(3,8)$ & $1(1,9)$ & $53(100)$ & $44(84,6)$ & 0 & $8(15,4)$ & $52(100)$ \\
\hline \multicolumn{2}{c}{ Keterangan: N= Normal NT= Normal Tinggi T= Tinggi }
\end{tabular}

Tabel 4. Nilai mean, median, simpang baku, minimum, maximum TDS pada anak laki-laki

\begin{tabular}{cccccc}
\hline Daerah & Mean & Median & $\begin{array}{c}\text { Simpangan } \\
\text { Baku }\end{array}$ & Minimum & Maksimum \\
\hline Pegunungan & 90,3 & 90 & 9,6 & 70 & 110 \\
\hline Tepi Pantai & 94,1 & 90 & 11,3 & 80 & 120 \\
\hline
\end{tabular}

Keterangan: tekanan darah sistolik

Tabel 5. Nilai mean, median, simpang baku, minimum, maximum TDD pada anak laki-laki

\begin{tabular}{cccccc}
\hline Daerah & Mean & Median & $\begin{array}{c}\text { Simpangan } \\
\text { Baku }\end{array}$ & Minimum & Maksimum \\
\hline Pegunungan & 62,1 & 60 & 6,8 & 50 & 80 \\
Tepi Pantai & 64,7 & 60 & 9,7 & 40 & 80 \\
\hline Keterangan: TDD tekanan darah diastolik & & &
\end{tabular}

Tabel 6. Nilai mean, median, simpang baku, minimum, maximum TDS

\begin{tabular}{cccccc}
\hline Daerah & Mean & Median & $\begin{array}{c}\text { Simpangan } \\
\text { Baku }\end{array}$ & Minimum & Maksimum \\
\hline Pegunungan & 88,7 & 90 & 9,4 & 70 & 110 \\
Tepi Pantai & 93,5 & 90 & 10,9 & 80 & 120 \\
\hline
\end{tabular}

Keterangan: TDS tekanan darah sistolik 
Jufri, Umboh, Masloman: Perbedaan tekanan darah...

Tabel 7. Nilai mean, median, simpang baku, minimum, maximum TDD

\begin{tabular}{cccccc}
\hline Daerah & Mean & Median & $\begin{array}{c}\text { Simpangan } \\
\text { Baku }\end{array}$ & Minimum & Maksimum \\
\hline Pegunungan & 63,7 & 60 & 7,1 & 50 & 80 \\
Tepi Pantai & 66 & 70 & 8,7 & 50 & 80 \\
\hline
\end{tabular}

Keterangan: TDD tekanan darah diastolik

Tabel 8. Hasil analisa perbandingan TDS dan TDD pada anak laki-laki

\begin{tabular}{ccc}
\hline Daerah & $\mathrm{Z}$ & $\mathrm{P}$ \\
\hline Sistolik Pegunungan dan Tepi Pantai & $-1,146$ & 0,126 \\
Diastolik Pegunungan dan Tepi Pantai & $-1,055$ & 0,146 \\
\hline Keterangan: TDS dan TDD pada anak laki-laki & &
\end{tabular}

Tabel 9. Hasil analisa perbandingan TDS dan TDD pada anak perempuan

\begin{tabular}{ccc}
\hline Daerah & $\mathrm{Z}$ & $\mathrm{P}$ \\
\hline Sistolik Pegunungan dan Tepi Pantai & $-1,513$ & 0,065 \\
Diastolik Pegunungan dan Tepi Pantai & $-1,084$ & 0,139 \\
\hline \multicolumn{2}{l}{ Keterangan: TDS dan TDD pada anak perempuan }
\end{tabular}

\section{BAHASAN}

Mengingat luasnya daerah pegunungan dan tepi pantai (pesisir), maka peneliti hanya memfokuskan penelitian ini untuk daerah pegunungan pada SD Inpres Wulurmaatus di Kecamatan Modoinding Kabupaten Minahasa Selatan dengan ketinggian $\pm 1200 \mathrm{~m}$ dari permukaan laut. Untuk daerah tepi pantai, penelitian dilakukan pada SD Inpres 12/79 Wangurer di Kecamatan Madidir Kota Bitungdengan harak dari tepi pantai ke lokasi $\pm 400 \mathrm{~m}$ dan dengan ketinggian 0-3 m dari permukaan laut.

Berdasarkan karakteristik jenis kelamin, secara keseluruhan didapatkan anak laki-laki sebanyak 52 (49,5\%) dan anak perempuan sebanyak 53 (50,5\%). Pada daerah pegunungan anak laki-laki mempunyai jumlah sedikit lebih banyak daripada anak perempuan, sedangkan daerah tepi pantai terdapat anak perempuan yang lebih banyak daripada anak laki-laki, (Tabel 1). Anak laki-laki di ke-2 daerah mempunyai tekanan darah sistolik tinggi sama banyak (1,9\%), sedangkan pada anak perempuan hanya di temukan tekanan darah sistolik normal tinggi pada tepi pantai (1,9\%) (Tabel 2). Sedangkan untuk tekanan darah diastolik anak laki-laki di pegunungan mempunyai tekanan darah dastolik normal tinggi (3,8\%) dan tinggi (1,8\%), lebih banyak tekanan darah diastolik tinggi pada anak yang ada di tepi pantai yaitu (5,8\%). Tekanan darah diastolik tinggi juga hanya ditemukan pada anak perempuan yang berada di tepi pantai (9,6\%) (Tabel 3). Hasil penelitian ini mirip dengan yang dilaporkan oleh Ariani dkk dalam penelitiannya di Provinsi Sumatera Utara didapatkan tekanan darah diastolik anak yang tinggal di daerah pesisir pantai Kecamatan pantai cermin lebih tinggi daripada anak yang tinggal di daerah pegunungan Kecamatan Brastagi. Tapi seperti yang dilaporkan meskipun berbeda tapi secara statistik tidak terdapat perbedaan yang bermakna. ${ }^{9}$

Berdasarkan hasil analisa yang dilakukan melalui uji Mann-Whitney test, bahwa tidak ada perbedaan antara tekanan darah sistolik pada anak laki-laki yang tinggal di pegunungan dan di tepi pantai, dengan nilai $\rho=0,126(>0,05)$, dan tidak terdapat juga perbedaan antara tekanan darah diastolik pada anak laki-laki yang tinggal di pegunungan dan di tepi pantai, dengan nilai $\rho=0,146(>0,05)$ yang artinya secara statistik tidak bermakna. Begitu juga di temukan tidak ada perbedaan tekanan 
darah sistolik pada anak perempuan yang tinggal di pegunungan dan tinggal di tepi pantai, dengan nilai $\rho=0,065(>0,05)$, serta perbedaan tekanan darah diastolik pada anak perempuan dikedua tempat dengan nilai $\rho=0,139(>0,05)$. Meskipun dari hasil pemeriksaan tekanan darah berbeda tapi secara statistik tidak terdapat perbedaan yang bermakna.

Dalam penelitian ini lingkungan tempat tinggal ke dua daerah sangatlah jauh berbeda.Dimana tekanan udara pada daerah tepi pantai (dataran rendah) lebih tinggi daripada daerah pegunungan (dataran tinggi).Semakin tinggi suatu tempat semakin rendah tekanan udaranya.Hal ini berkaitan dengan adanya faktor gravitasi bumi. Kandungan oksigen yang rendah di dataran tinggi dalam jangka waktu yang lama akan mengakibatkan produksi sel darah merah meningkat sebagai adaptasi fisiologi tubuh. Peningkatan ini berkaitan dengan viskositas darah, yang merupakan faktor yang mempengaruhi laju aliran darah melalui suatu pembuluh (resistensi). Semakin besar viskositas semakin besar resistensi terhadap aliran,sehingga aliran darah menjadi lebih lambat daripada normal. ${ }^{10,11}$

\section{SIMPULAN}

Dari hasil penelitian yang diperoleh maka dapat disimpulkan bahwa tidak ada perbedaan tekanan darah pada anak yang berumur 6-12 tahun yang tinggal di pegunungan dan di tepi pantai.

\section{SARAN}

Pada anak-anak yang memilik tekanan darah sitolik dan diastolik normal tinggi (pre-hipertensi) ataupun tinggi (hipertensi) perlu di lakukan pengukuran tekanan darah secara rutin, untuk mendeteksi adanya kenaikan tekanan darah pada anak.

\section{DAFTAR PUSTAKA}

1. Gunawan L. Hipertensi Tekanan Darah Tinggi. Yogyakarta: Kaninus, 2001;p. 7.

2. Guyton AC, Hall JE. Textbook of medical physiology. $11^{\text {th }}$ ed. Philadelphia: Elsevier Saunders, 2006.

3. Partha. Hipertensi pada anak. Indian J Ped 2002:6:1077-81.

4. Sherwood L. Fisiologi manusia dari sel ke sistem. $\quad$ Ed $2 . \quad$ Jakarta: EGC,1996:p.128.

5. Buch N, Goyal JP, Kumar N, Palmar I, Shah VB, Charan J. Prevelence of hypertension in school going children of Surat City, Western India. JCDR 2011 Nov;2(4):228-32.

6. Departemen Kesehatan RI. Laporan hasil riset kesehatan dasar 2007, Jakarta: Badan Penelitian dan Pengembangan Kesehatan Departemen Kesehatan Republik Indonesia;2007.

7. Badan Litbang Kesehatan Departemen Kesehatan RI. Hipertensi di Indonesia Riset Kesehatan Dasar (RISKESDAS) 2013.

8. Bustan M. Epidemiologi penyakit tidak menular. Jakarta: Rineka Cipta. 2007.

9. Ariani A, Lisma TE, Lubis IZ, Ramayati R. Study of blood pressure in elementary school children at hill and seashore areas. Peadiatrica Indonesiana. 2003;43:7-8

10.Ethel S. anatomi dan Fisiologi untuk pemula. Editor; Palupi Widayastuti. Anatomy and physiology: an easy learner. Jakarta: EGC; 2004. p. 22122.

11.Lauralee S. Fisiologi manusia: dari sel ke system. Ed-6, Editor; Nella Yesdelita. Human physiology: from cells to systems. Jakarta: EGC; 2013. p. 371,400-5. 